\title{
Effects of Irrigation and Verticillium dahliae on Cauliflower Root and Shoot Growth Dynamics
}

\author{
C. L. Xiao and K. V. Subbarao
}

Department of Plant Pathology, University of California, Davis, c/o United States Agricultural Research Station, 1636 E. Alisal Street, Salinas 93905.

Current address of C. L. Xiao: Washington State University, Tree Fruit Research and Extension Center, 1100 North Western Avenue, Wenatchee 98801.

Accepted for publication 26 May 2000.

\begin{abstract}
Xiao, C. L., and Subbarao, K. V. 2000. Effects of irrigation and Verticillium dahliae on cauliflower root and shoot growth dynamics. Phytopathology 90:995-1004.

Cauliflower root and plant growth and Verticillium wilt development were evaluated under different moisture regimes in the presence or absence of $V$. dahliae. Treatments included two main plots ( $V$. dahliaeinfested and fumigated), two subplots (furrow and subsurface drip irrigation), and three sub-subplots (deficit, moderate, and excessive regimes) that were arranged in a split-split-plot design in the field. Soil cores with roots were periodically sampled at 5 and $25 \mathrm{~cm}$ distance from plants. Total roots in each soil core were extracted with a hydropneumatic root elutriator, and root length from each sample was determined with a digital image analysis system. Incidence and severity of Verticillium wilt, plant height, number of leaves, and dry weights of leaves and roots were determined on 10 plants sampled at 7- to 10-day intervals 1 month after cauliflower transplanting and continued until harvest. To evaluate

nificantly $(P<0.05)$ higher in subsurface drip than in furrow irrigation. Root length density was significantly higher in excessive irrigation regime than in the other regimes. Concomitantly, there was higher wilt incidence and severity in excessive and moderate regimes than deficit regime regardless of the irrigation method. Plant height was affected by irrigation methods and deficit regime. Neither the method of irrigation nor the quantity of water affected the other variables. Stomatal resistance in lower diseased leaves was significantly higher in infested than in fumigated plots but it was not in the upper healthy leaves. In this study, cauliflower yield was not affected by $V$. dahliae and irrigation method, but the deficit irrigation regime resulted in reduced yield even though it suppressed wilt in cauliflower. Thus, higher moisture levels resulted in higher root length density in $V$. dahliae-infested plots that in turn lead to greater incidence of Verticillium wilt and severity. The pathogen also affected physiological processes such as hydraulic conductance of cauliflower leaves, but not shoot growth or yield under these experimental conditions.
\end{abstract} the effects of Verticillium wilt-induced stress on cauliflower plants, stomatal resistance was measured in upper healthy and lower (or diseased) leaves. Root length density at 5 and $25 \mathrm{~cm}$ from plant was sig-
Additional keywords: epidemiology, pathogen-induced stress, soilborne pathogens.
Verticillium dahliae Kleb. is a widely distributed soilborne pathogen causing vascular wilt on many economically important crops $(21,23)$. Soil infested with microsclerotia is the principal inoculum source for Verticillium wilt development. Microsclerotia are stimulated to germinate in the rhizosphere or its vicinity by root exudates; they penetrate plant roots and invade the vascular tissue (21). Infection can occur at any time during the crop growth. Root growth is an important component in the progress of diseases caused by root pathogens and is of particular importance to the epidemiology of root diseases because it probably best reflects the number of potential root and pathogen contact sites (11). The response distance of $V$. dahliae microsclerotia to root exudates is $\approx 100$ to $300 \mu \mathrm{m}(4,11)$. Thus, extensive growth of host root systems is more important in initial pathogen-root interactions relative to the mobility of the pathogen, because microsclerotia of $V$. dahliae are relatively immobile in the soil.

Soil moisture is a major factor affecting root growth rate and distribution (11). In cotton, increases in root densities ceased at soil water potentials $\approx-0.1 \mathrm{MPa}$, and decreased significantly with further drying of the soil (11). Under growth chamber conditions, however, potato root length was reduced at $-0.01 \mathrm{MPa}$ compared with roots of plants grown at water potentials of less than $-0.15 \mathrm{MPa}(8,19)$.

Corresponding author: K. V. Subbarao; E-mail address: kvsubbarao@ucdavis.edu

Publication no. P-2000-0710-01R

(c) 2000 The American Phytopathological Society
In many crops, $V$. dahliae causes chlorosis, stunting, premature defoliation, and wilting (21). Verticillium wilt on cotton reduces plant height, lateral branching, and dry matter accumulation in leaves, stems, roots, and bolls in field $(1,20)$. Potato plants also show reduced leaf area and function following infection with $V$. dahliae due to reduced leaf development, leaf chlorosis, and premature defoliation $(10,19)$. In eggplant, Verticillium wilt results in stunted growth and reduced yields (9).

$V$. dahliae causes water stress in host plants by decreasing the hydraulic conductance of the xylem (21). Physiological responses of cotton (25) and potato (2) plants infected with $V$. dahliae include increased stomatal resistance in the leaves of diseased plants. Increased stomatal resistance reduces the concentration of $\mathrm{CO}_{2}$ in the leaf, and net photosynthesis is affected $(2,3)$. Under microplot conditions (28), $V$. dahliae resulted in increased stomatal resistance in lower diseased leaves, uniform stomatal resistance in upper healthy leaves of cauliflower, and noticeable shoot and root growth reductions when inoculum density was greater than 10 microsclerotia per $g$ of soil. This has not been further demonstrated under field conditions (28).

Cauliflower (Brassica oleracea L. var. botrytis L.) has been severely affected by $V$. dahliae in recent years. Verticillium wilt on cauliflower causes chlorosis of lower leaves, defoliation, wilting, and vascular discoloration resulting in reduced size and quality of harvested flower heads (14). In coastal California, cauliflower is grown under furrow and subsurface drip irrigation (26). Our previous study indicated that wilt development was not significantly 

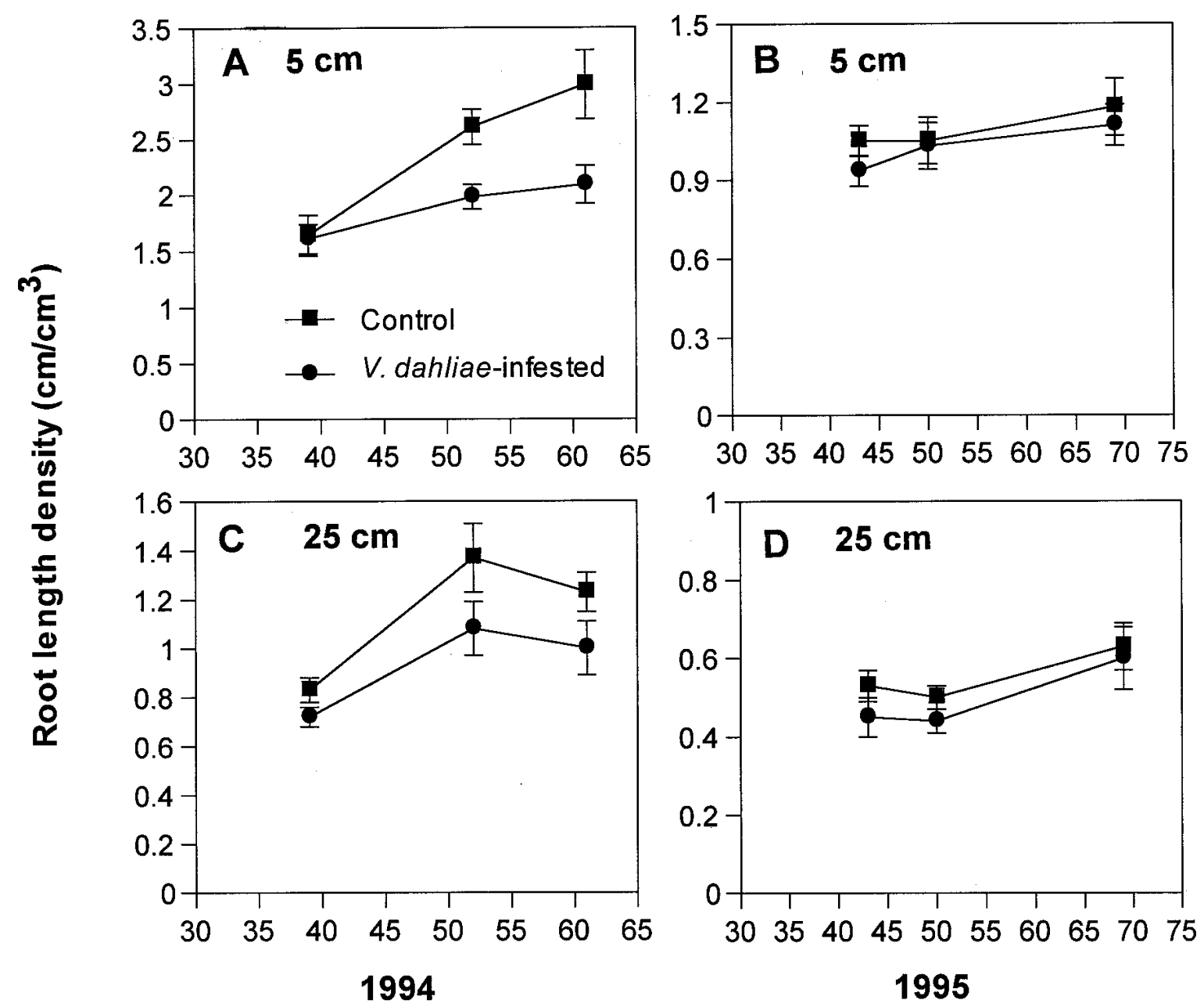

\section{Days after planting}

Fig. 1. Root length densities of cauliflower in Verticillium dahliae-infested and fumigated soil at 5 and $25 \mathrm{~cm}$ from plant in 1994 and 1995 . Vertical bars are the standard errors of the mean.

TABLE 1. Mean square (MS) and probability of the $F$ test $(P<F)$ for the effects of soil infestation (Verticillium dahliae-infested and fumigated control), irrigation methods (furrow and subsurface drip), and irrigation regimes (excessive, moderate, and deficit) on root length densities of cauliflower in 1994 and 1995

\begin{tabular}{|c|c|c|c|c|c|c|c|}
\hline \multirow[b]{2}{*}{ Year } & \multirow[b]{2}{*}{ Source of variation } & \multicolumn{3}{|c|}{ Root length density $(5 \mathrm{~cm})$} & \multicolumn{3}{|c|}{ Root length density $(25 \mathrm{~cm})$} \\
\hline & & df & MS & $P>F$ & df & MS & $P>F$ \\
\hline \multirow{7}{*}{1994} & Block & 2 & 0.7800 & 0.1954 & 2 & 0.0072 & 0.9539 \\
\hline & Irrigation methods & 1 & 5.2234 & 0.0131 & 1 & 0.4187 & 0.3273 \\
\hline & Soil $\times$ irrigation & 1 & 0.5358 & 0.2443 & 1 & 0.0004 & 0.9745 \\
\hline & Block $\times$ irrigation & 4 & 0.2881 & $\ldots$ & 4 & 0.3367 & 列 \\
\hline & Irrigation $\times$ regime & 2 & 1.4844 & 0.0569 & 2 & 0.0241 & 0.8550 \\
\hline & Soil $\times$ irrigation $\times$ regime & 2 & 0.0357 & 0.9208 & 2 & 0.1081 & 0.5073 \\
\hline & Residual & 16 & 0.4307 & $\ldots$ & 16 & 0.1526 & $\ldots$ \\
\hline \multirow[t]{8}{*}{1995} & Block & 2 & 0.0484 & 0.6961 & 2 & 0.0269 & 0.3582 \\
\hline & Soil infestation & 1 & 0.1354 & 0.3814 & 1 & 0.0690 & 0.3867 \\
\hline & Block $\times$ soil & 2 & 0.1092 & $\ldots$ & 2 & 0.0572 & \\
\hline & Irrigation $\times$ regime & 2 & 0.1424 & 0.3603 & 2 & 0.0981 & 0.0431 \\
\hline & Soil $\times$ irrigation $\times$ regime & 2 & 0.0183 & 0.8701 & 2 & 0.0508 & 0.1623 \\
\hline & Residual & 16 & 0.1308 & $\ldots$ & 16 & 0.0242 & 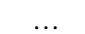 \\
\hline & Time $\times$ irrigation $\times$ regime & 4 & 0.909 & 0.8310 & 4 & 0.388 & 0.0190 \\
\hline & Time $\times$ soil $\times$ irrigation $\times$ regime & 4 & 0.693 & 0.2245 & 4 & 0.624 & 0.2086 \\
\hline
\end{tabular}


different between these two irrigation methods, but deficit irrigation regimes reduced wilt on cauliflower regardless of irrigation methods (29). Because the different irrigation regimes are expected to result in different moisture regimes, root growth under these conditions is also expected to be different. Information on how these affect wilt development in cauliflower is needed to recommend the irrigation methods and regimes to follow for wilt management.

The objectives of this study were to determine root and shoot growth dynamics in $V$. dahliae infested and fumigated soils under furrow and subsurface drip irrigation systems with different watering regimes, and to determine stomatal resistance in cauliflower leaves under these conditions. A preliminary report has been published (27).

\section{MATERIALS AND METHODS}

Field plots. All experiments were conducted at the U.S. Agricultural Research Station in Salinas, CA. The soil was Antioch sandy loam $(45.8 \%$ sand, $43.4 \%$ silt, $8.8 \%$ clay, and $1.8 \%$ organic matter) with a $\mathrm{pH}$ of 6.1 . The experimental plots were fumigated in 1994 with a mixture of methyl bromide and chloropicrin (50:50, $\mathrm{vol} / \mathrm{vol}$ ) at $444 \mathrm{~kg} / \mathrm{ha}$ in the spring before treatments were established. The fumigants were injected at a depth of $20 \mathrm{~cm}$ under continuous plastic tarpaulin. After the removal of plastic tarpaulin, beds were shaped and the irrigation treatments were established. The experimental design was a $2 \times 2 \times 3$ factorial combination of treatments arranged in a split-split-plot design with three replications. Main plots were $V$. dahliae-infested and fumigated control (only summer cauliflower planted each year), the subplots included furrow and subsurface drip irrigation, and the sub-subplots included deficit, moderate, and excessive irrigation regimes. Each treatment combination (sub-sub-plot) was six beds wide $(1 \mathrm{~m}$ between bed centers) and $9 \mathrm{~m}$ long. The subplots were separated by $2 \mathrm{~m}$, and the main plots were separated by $6 \mathrm{~m}$ of bare soil to reduce plot interactions.

The procedure for infesting plots with $V$. dahliae microsclerotia has been described previously (29). Briefly, the central four beds of each sub-subplot in the $V$. dahliae-infested main plots were treated with infested soil from a cauliflower field. The infested soil was mixed to a depth of $25 \mathrm{~cm}$ with a Marvin incorporator. Soil from three to four arbitrarily chosen sites on each bed was collected from each sub-subplot immediately after soil infestation for $V$. dahliae assay and plated on sodium polypectate agar (NP-10) selective medium according to the Anderson sampler technique (5). In 1994, initial inoculum density after artificial soil infestation was 19 microsclerotia per $g$ of soil. In 1995 , the inoculum density at planting was $\approx 80$ microsclerotia per gram of soil. The inoculum augmentation in 1995 was caused by the formation of microsclerotia on infected roots and other tissues that remained in the soil after the 1994 harvest.

Five-week-old transplants of susceptible cauliflower cv. White Rock were planted in all plots in single rows with a $25-\mathrm{cm}$ spacing between plants on 24 June 1994 and 5 July 1995. Sprinklers irrigated all plots for 10 days to facilitate transplant establishment, after which the irrigation treatments were begun. The amount of water applied for each irrigation method and regimes within meth-
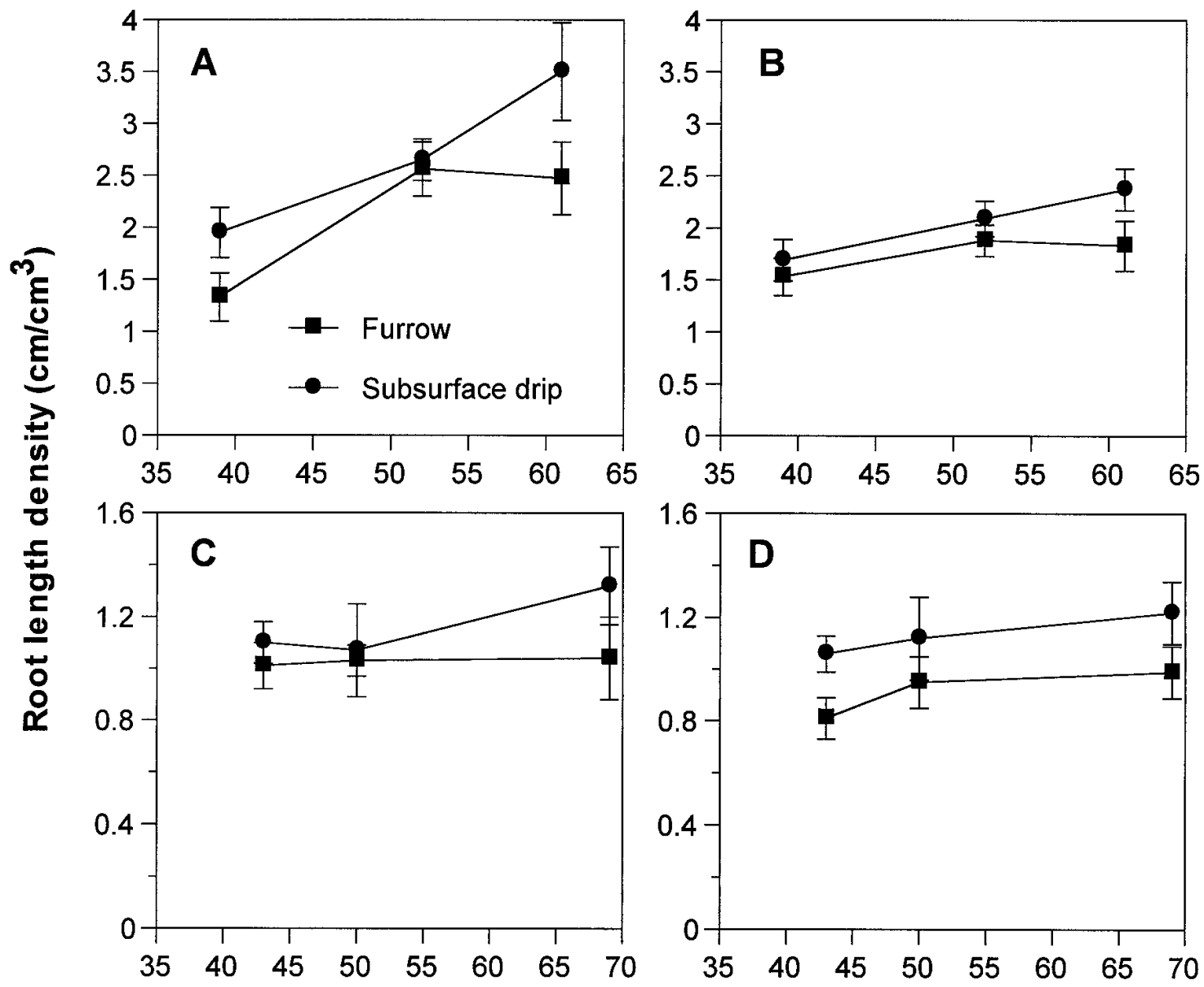

\section{Days after planting}

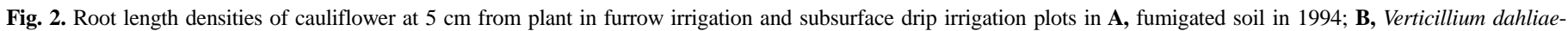
infested soil in 1994; C, fumigated control in 1995; and D, V. dahliae-infested in 1995. Vertical bars are the standard errors of the mean. 
ods was calculated based on the crop coefficients for cauliflower and evapotranspiration rates for the Salinas area (26). For furrowirrigated plots, water was applied once every 4, 8, and 12 days for excessive, moderate, and deficit treatments, respectively. For subsurface drip irrigation, water was applied every other day, twice a week, and once a week for excessive, moderate, and deficit treatments, respectively.

The crop was managed according to commercial recommendations for cauliflower (26). In furrow-irrigated plots, a urea-nitrate fertilizer (Wilbur-Ellis Co., Salinas, CA) was applied to furrows at the rate of $124 \mathrm{~kg} / \mathrm{ha}$ at 3 -week-intervals. Plots were irrigated immediately after fertilization. In subsurface drip-irrigated plots, a liquid formulation of nitrogen was applied through the irrigation system at rates similar to the furrow system.

In each plot, soil moisture was recorded by gypsum blocks (Soil Moisture Equipment Co., Santa Barbara, CA) placed at 10 and $25 \mathrm{~cm}$ depths. The resistance of gypsum blocks was recorded at 2-day intervals and converted to water potential (MPa) based on the charts provided by the manufacturer.

Root length assessment. To quantify root length density, soil was sampled 39, 52, and 61 days after planting in 1994 and 42, 50, and 69 days after planting in 1995 from each sub-subplot with a 4.5 -cm-diameter soil probe to a depth of $15 \mathrm{~cm}$. Soil cores were collected from 5 and $25 \mathrm{~cm}$ distance on either side of the plant perpendicular to the row direction and between the plants along the row direction. Soil cores collected at the same distance from both sides from plant were combined and thoroughly mixed. Half of the composted soil was subsampled for further processing. Total roots in each subsampled soil were extracted by a hydropneumatic root elutriator (22) and stored in $10 \%$ isopropyl alcohol in a 120 -ml polypropylene specimen container at $4^{\circ} \mathrm{C}$ until root length measurements were taken. Root length from each sample was determined by a Digital Image Analysis System (DIAS II, Decagon Devices Inc., Pullman, WA). Roots from each sample were washed, separated from nonroot materials such as weed seeds and debris, and stained with methyl violet for $12 \mathrm{~h}$ before measurements were taken. Stained roots were floated in 1 to $3 \mathrm{~mm}$ of water in a glass-bottomed root tray, and spread by tweezers so roots did not overlap. If root samples were too large, samples were divided into two or more subsamples before root length measurements were made. Subsamples were added to obtain total root length. Root length density $\left(\mathrm{cm} \mathrm{cm}^{-3}\right)$ from each soil core was determined based on the total root length and the volume of the core.

Plant growth parameters and disease assessment. Shoot growth and Verticillium wilt development on cauliflower were assessed at 7- to 10-day-intervals from 1 month after transplanting until crop maturity. Ten plants randomly collected from each subsubplot were uprooted and washed free of soil. Plant height and
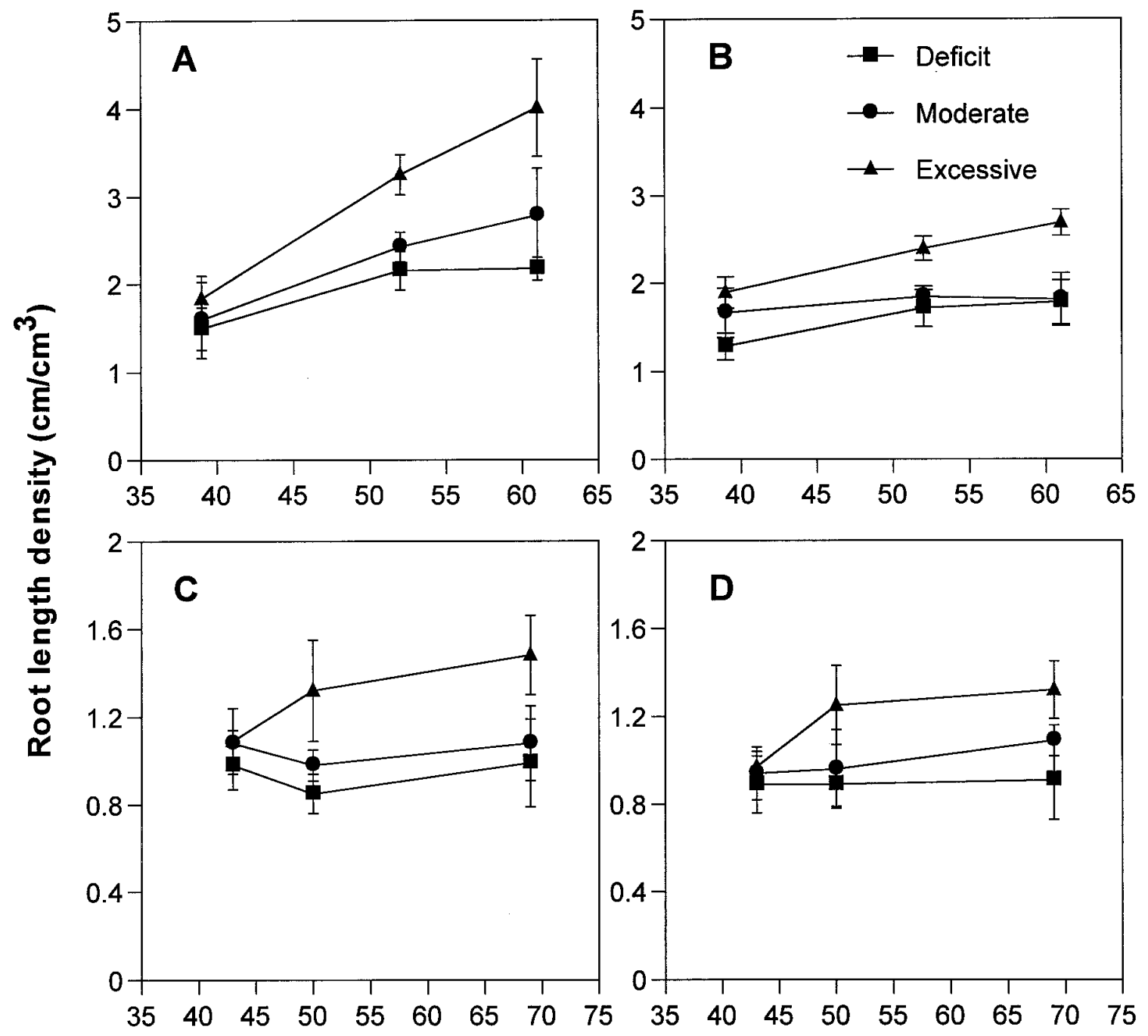

\section{Days after planting}

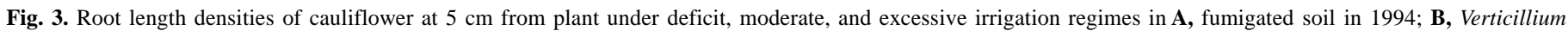
dahliae-infested soil in 1994; C, fumigated control in 1995; and D, V. dahliae-infested in 1995. Vertical bars are the standard errors of the mean. 
number of leaves were determined for each plant. The stem and root portion of each plant was longitudinally split to estimate the percentage of vascular tissue discolored (wilt severity), on a scale of 0 to 5: $0=$ no discoloration; $1=1$ to $10 \%$ discoloration; $2=11$ to $30 \%$ discoloration; $3=31$ to $50 \%$ discoloration; $4=51$ to $75 \%$ discoloration; and $5=76$ to $100 \%$ discoloration. Wilt incidence was expressed as proportion of plants with vascular discoloration in 10 sampled plants. Pieces of diseased root and stem tissue from five plants from each sub-subplot were surface sterilized, plated on NP-10 selective medium, and incubated at room temperature ( 22 to $24^{\circ} \mathrm{C}$ ). Plant tissue on plates was examined periodically for the development of $V$. dahliae colonies. Subsequent to the disease evaluations, the total dry weights of leaves and roots were determined after oven drying at $70^{\circ} \mathrm{C}$.

Stomatal resistance. Stomatal resistance was measured twice each season, and the first measurement was taken when foliar wilt symptoms were not widespread in the plots $(\approx 30$ days after transplanting). Two upper visually healthy and two lower leaves in each sub-subplot were selected and the stomatal resistance of the leaves was measured by a porometer (Delta-T Devices Ltd., England). The second measurement was taken later in the season when foliar wilt symptoms were widespread in the plots. Two upper visually healthy and two lower disease-induced chlorotic leaves in each sub-subplot were selected for the measurement. The measurements were taken only on sunny days between 1300 and 1500 hours. For each individual leaf, the mean of five repeated readings of the porometer was used. The porometer readings were converted to stomatal resistance $\left(\mathrm{s} \mathrm{cm}^{-1}\right)$ with a calibration curve from the corresponding day.

Yield. At crop maturity, cauliflower heads were harvested from each sub-subplot, sorted by size, and graded as marketable and unmarketable. Ten marketable heads from each sub-subplot were randomly chosen to determine their weight.

Data analyses. Repeated measures analysis of variance was performed on root length densities from different sampling dates, plant growth parameters, Verticillium wilt incidence, and severity over time. Because the majority of disease incidence data from fumigated control plots were 0 , only the data from $V$. dahliae-infested treatment were included in the analysis. Repeated measures analysis of variance was performed using the SAS General Linear Models procedure (version 6.12, SAS Institute, Cary, NC) with REPEATED option. Time interactions were tested with Wilks' $\lambda$. Analysis of variance was conducted on final plant growth parameters (at harvest) and on final wilt incidence and severity data from the fumigated control and the infested treatments. Means were tested by least significant difference (LSD) at $P=0.05$. When interactions were significant, mean separations were performed using PROC Mixed procedure in which pairwise comparisons of means using $t$ tests were obtained by the PDIFF option on the LEMEANS statement. Similarly, data on stomatal resistance and yield were analyzed by analysis of variance to determine treatment effects, and mean comparisons were determined by $\operatorname{LSD}(P=0.05)$.
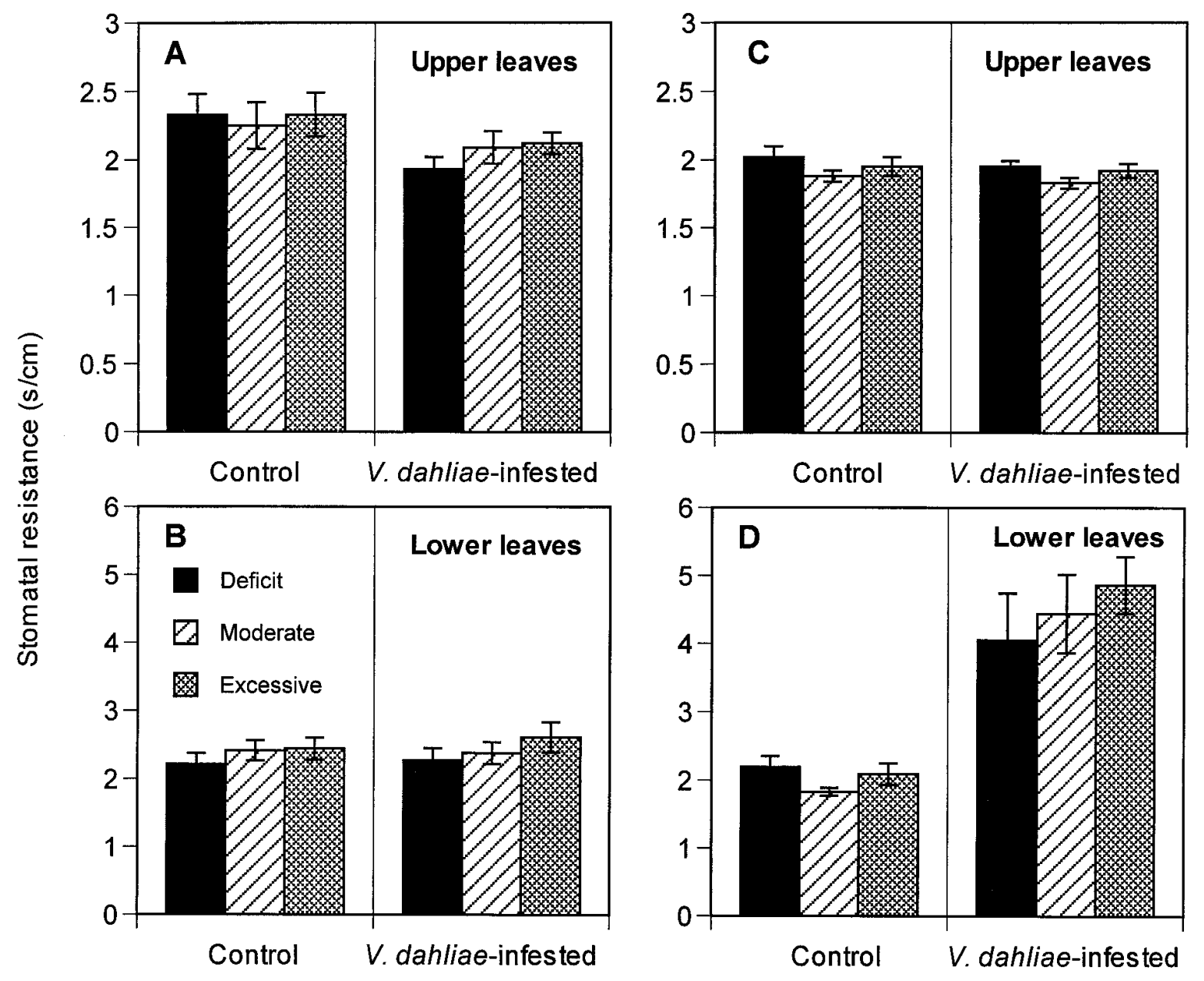

7 Wk post-transplanting

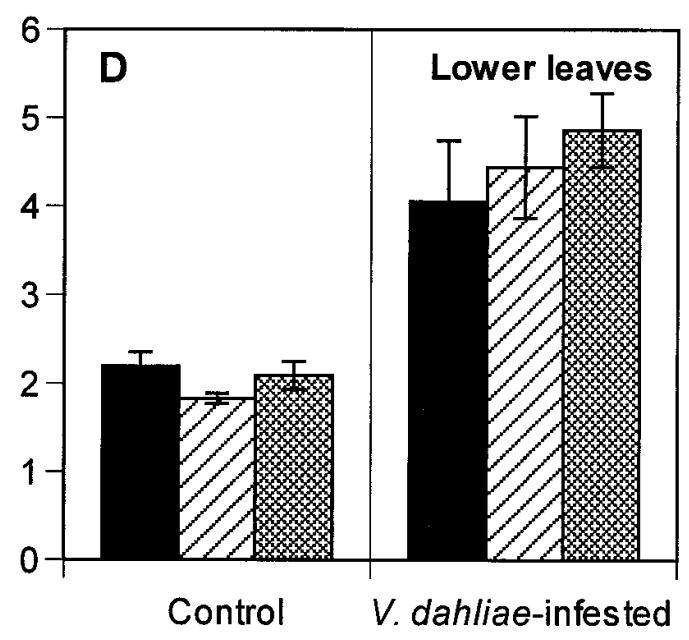

9 Wk post-transplanting

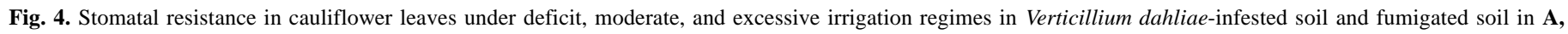

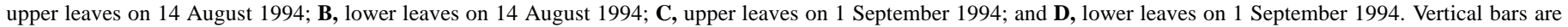
the standard errors of the mean. 


\section{RESULTS}

Root length density. Repeated measures analysis of variance indicated that in 1994 root length densities at both 5 and $25 \mathrm{~cm}$ from plants were significantly different between $V$. dahliaeinfested and fumigated control. No differences between the two treatments were observed at either distance in 1995 (Table 1 and Fig. 1). In 1994, root length density at $5 \mathrm{~cm}$ from plant was significantly higher under subsurface drip irrigation than under furrow irrigation, but at $25 \mathrm{~cm}$ it was similar in both irrigation methods. In 1995, root length density at $5 \mathrm{~cm}$ from plant was not different between irrigation methods, but at $25 \mathrm{~cm}$ it was significantly higher under furrow irrigation than under subsurface drip irrigation (Table 1 and Fig. 2). The effects of irrigation regimes on root length densities at both 5 and $25 \mathrm{~cm}$ from plants in 1994 and 1995 were identical in $V$. dahliae-infested and fumigated control plots (Table 1). At 5 and $25 \mathrm{~cm}$ from plants, root length densities were significantly higher under excessive irrigation regime than under other regimes in 1994 and 1995 (Table 1 and Fig. 3).

Time effects were significant for root length densities at $5 \mathrm{~cm}$ $(P=0.0001)$ and $25 \mathrm{~cm}(P=0.0419)$ from plants but not at $5 \mathrm{~cm}$ in $1995(P=0.1897)$. Time $\times$ soil infestation (main plots) interactions were not significant in either year $(P>0.05)$ suggesting that the root length densities in the two main plots ( $V$. dahliae-infested and fumigated) varied with time similarly. All other interactions with time such as time $\times$ irrigation method and time $\times$ irrigation regime were not significant at 5 and $25 \mathrm{~cm}$ from plants in either year $(P>0.05$; Fig. 1$)$.

In 1994, soil water potentials in furrow-irrigated plots ranged between -0.037 to $-1.235,-0.034$ to -0.875 , and -0.021 to $-0.058 \mathrm{MPa}$

TABLE 2. Plant height, number of leaves, dry weight of leaf and root of cauliflower in treatments at the end of the season in 1994 and 1995

\begin{tabular}{llrrrr}
\hline Year & Treatment & $\begin{array}{c}\text { Plant height } \\
(\mathrm{cm})^{\mathrm{z}}\end{array}$ & $\begin{array}{r}\text { No. of } \\
\text { leaves }\end{array}$ & Leaf $(\mathrm{g})$ & Root $(\mathrm{g})$ \\
\hline \multirow{2}{*}{1994} & Control & 75.27 & 20.34 & 173.36 & 29.79 \\
& V. dahliae-infested & 75.39 & 21.01 & 186.29 & 27.08 \\
& LSD $(P=0.05)$ & 3.08 & 0.42 & 45.52 & 5.57 \\
& Furrow & 78.18 & 20.96 & 184.03 & 28.00 \\
Subsurface drip & 72.48 & 20.39 & 175.62 & 28.87 \\
LSD $(P=0.05)$ & NT* & 0.94 & 22.73 & 3.33 \\
Deficit & 73.01 & 20.65 & 174.16 & 28.31 \\
Moderate & 76.43 & 20.73 & 180.88 & 28.75 \\
Excessive & 76.49 & 20.64 & 184.43 & 28.24 \\
LSD $(P=0.05)$ & NT** & 0.87 & 20.29 & 2.22 \\
Control & 71.74 & 26.42 & 210.50 & 24.51 \\
V. dahliae-infested & 67.72 & 25.93 & 181.11 & 20.15 \\
LSD $(P=0.05)$ & 5.43 & 0.29 & 63.00 & 4.10 \\
Furrow & 72.84 & 26.41 & 189.15 & 21.28 \\
Subsurface drip & 66.62 & 25.94 & 202.46 & 23.38 \\
LSD $(P=0.05)$ & NT* & 1.59 & 31.80 & 2.30 \\
Deficit & 67.61 & 26.64 & 187.66 & 21.47 \\
Moderate & 71.95 & 25.45 & 208.55 & 22.67 \\
Excessive & 69.63 & 26.44 & 191.19 & 22.85 \\
LSD $(P=0.05)$ & 2.64 & 1.47 & 25.10 & 2.00 \\
\hline
\end{tabular}

${ }^{\mathrm{z}}$ All variables are means from three replications, 10 plants per replication. *Indicates not tested for mean separation by LSD due to soil infestation $\times$ irrigation interactions. Further analysis indicated that plant height was significantly higher in furrow than in subsurface drip irrigation in both $V$. dahliae-infested and fumigated soils. ** Indicates not tested for mean separation by LSD due to soil infestation $\times$ irrigation regimes interactions. Further analysis indicated that plant height was significantly lower in deficit regime than in the other irrigation regimes in fumigated soil. There were no significant differences in the three irrigation regimes in $V$. dahliaeinfested soil. for deficit, moderate, and excessive regimes, respectively. For subsurface drip irrigation, the values ranged between -0.027 to $-1.288,-0.021$ to -0.514 , and -0.019 to $-0.029 \mathrm{MPa}$ for deficit, moderate, and excessive regimes, respectively. The average values of water potential under the three irrigation regimes were within the ranges that favor pathogen activity (19).

Plant growth parameters. Repeated measures analysis of variance indicated that in both years plant height and dry weight of leaves were not significantly different between $V$. dahliae-infested and fumigated control. The number of leaves in 1994 and the dry weight of roots in 1995 were significantly different between the fumigated control and $V$. dahliae-infested treatments. The time effects were significant for all growth parameters. Time $\times$ soil infestation (main plots) was also significant for plant height and dry weight of roots in both 1994 and 1995 and dry weight of leaves in 1995 (data not shown).

Plant height was significantly higher in furrow than in subsurface irrigation method in 1994 and 1995. The number of leaves and the dry weights of leaves and roots were not signifi cantly different between the irrigation methods in 1994 and 1995. Irrigation method $\times$ soil infestation (main plots) did not affect plant growth parameters (except for plant height in 1994 and the number of leaves in 1995; data not shown). Plant height was significantly lower in deficit irrigation regime than in the other regimes, but the number of leaves and the dry weight of leaves and roots were not different among the three regimes in 1994

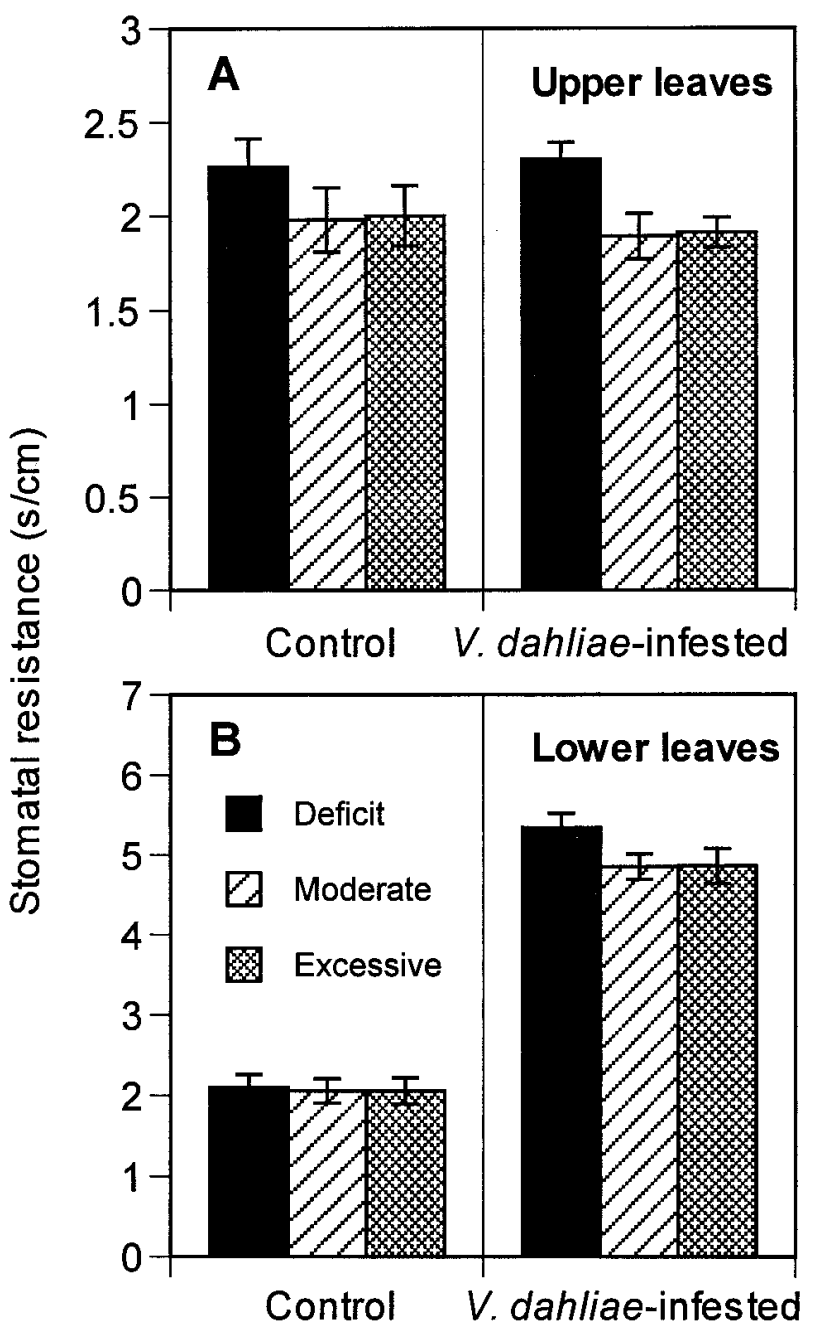

Fig. 5. Stomatal resistance in cauliflower leaves under deficit, moderate, and excessive irrigation regimes in Verticillium dahliae-infested soil and fumigated soil in A, upper leaves and B, lower leaves on 1 September 1995. Vertical bars are the standard errors of the mean. 
and 1995. There were no irrigation $\times$ regime effects on any of the growth parameters except plant height in 1994. Analyzing the data for all variables at harvest separately also provided similar results (Table 2).

Stomatal resistance. In 1994, stomatal resistance in upper healthy leaves was not significantly different between fumigated control and $V$. dahliae-infested treatments. Until 6 week posttransplanting, stomatal resistance in symptomless leaves was not significantly different between fumigated control and $V$. dahliaeinfested treatments (Fig. 4). When lower leaves exhibited wilt symptoms, stomatal resistance was significantly greater in infested than in fumigated control (Fig. 4). Stomatal resistance was not significantly different between irrigation methods, however, in the upper leaves it was significantly higher in deficit than in the other regimes (Fig. 4). Similarly, in 1995 stomatal resistance was higher in lower diseased leaves later in the season than in upper leaves. Stomatal resistance was significantly higher in deficit regime than in the others (Fig. 5).

Verticillium wilt incidence and severity. Repeated measures analysis of variance indicated that time effects were significant $(P<0.05)$ for both incidence and severity of Verticillium wilt. Time $\times$ irrigation method interaction was not significant $(P>0.05$; except for incidence in 1995); however, time $\times$ irrigation regime interaction was significant for wilt severity in 1995 (data not shown). Final disease incidence and severity were $84.7 \%$ and 1.77 in $V$. dahliae-infested plots and $0.69 \%$ and 0.01 in fumigated control in 1994 (Fig. 6), respectively. Final disease incidence and severity were $77.8 \%$ and 2.42 in $V$. dahliae-infested plots and $1.67 \%$ and 0.05 in fumigated control in 1995 (Fig. 7), respectively. Final wilt incidence and severity were not significantly $(P>0.05)$ different between furrow and subsurface drip irrigation in 1994 and 1995. Final wilt incidence was lower $(P<$ $0.05)$ in the deficit compared with moderate and excessive irrigation regimes in 1994 and 1995. Differences between moderate and excessive regimes, however, were not significant. Final wilt severity was lower $(P<0.05)$ in infested plots in the deficit than in the moderate and excessive irrigation regimes. Differences between moderate and excessive regimes were not significant (Figs. 6 and 7).

Yield. Analysis of variance indicated that there were no interactive effects of $V$. dahliae, irrigation methods, and regimes on cauliflower yield in 1994 and 1995 (data not shown). In 1994 and 1995, number of marketable heads, number of unmarketable heads, and weight of marketable heads were not significantly different between the fumigated control and $V$. dahliae-infested treatments, and were not significantly different between furrow and subsurface irrigation (Table 3). In 1994, the number of marketable heads and the weight of marketable heads were significantly higher in excessive irrigation regime than in other regimes. Deficit regime resulted in the lowest number of marketable heads and the corresponding weight, while excessive regimes had the lowest number of unmarketable heads (Table 3). In 1995, however, yield differences between irrigation regimes were not significantly different.

\section{V. dahliae-infested}
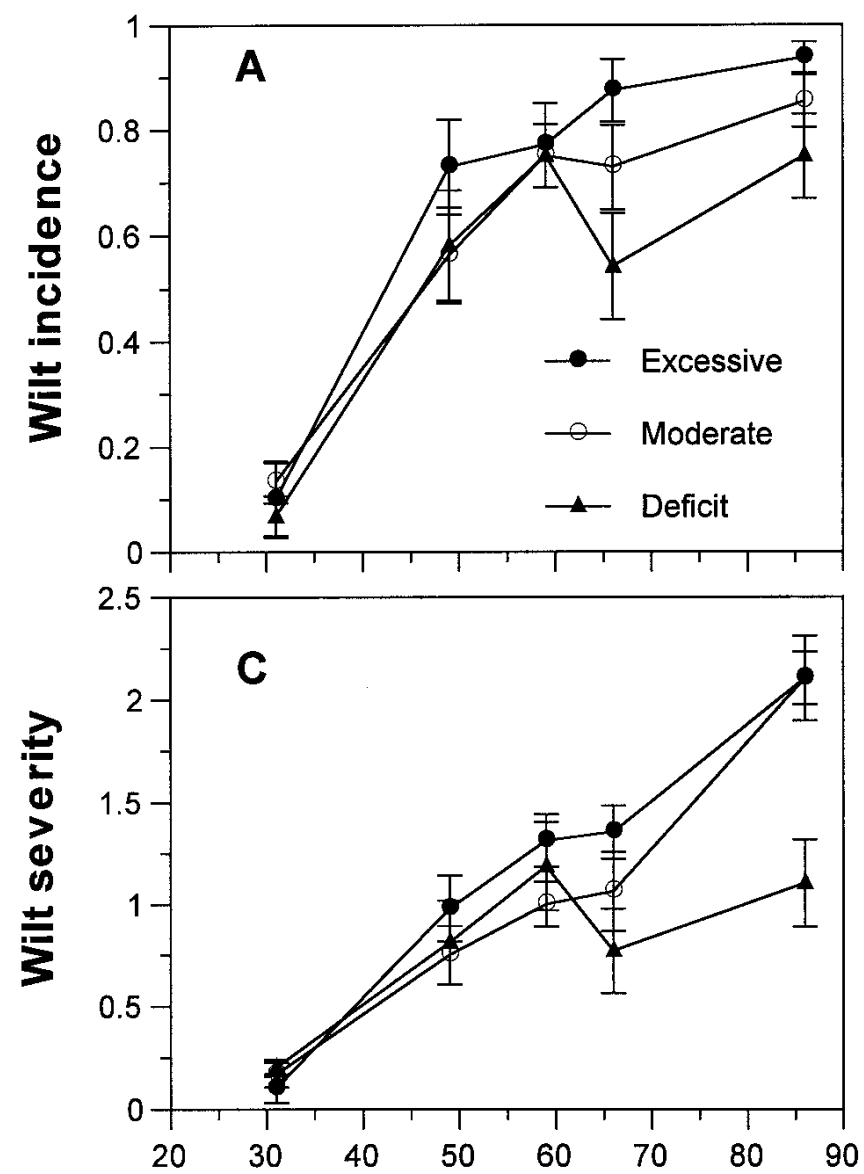

\section{Fumigated control}
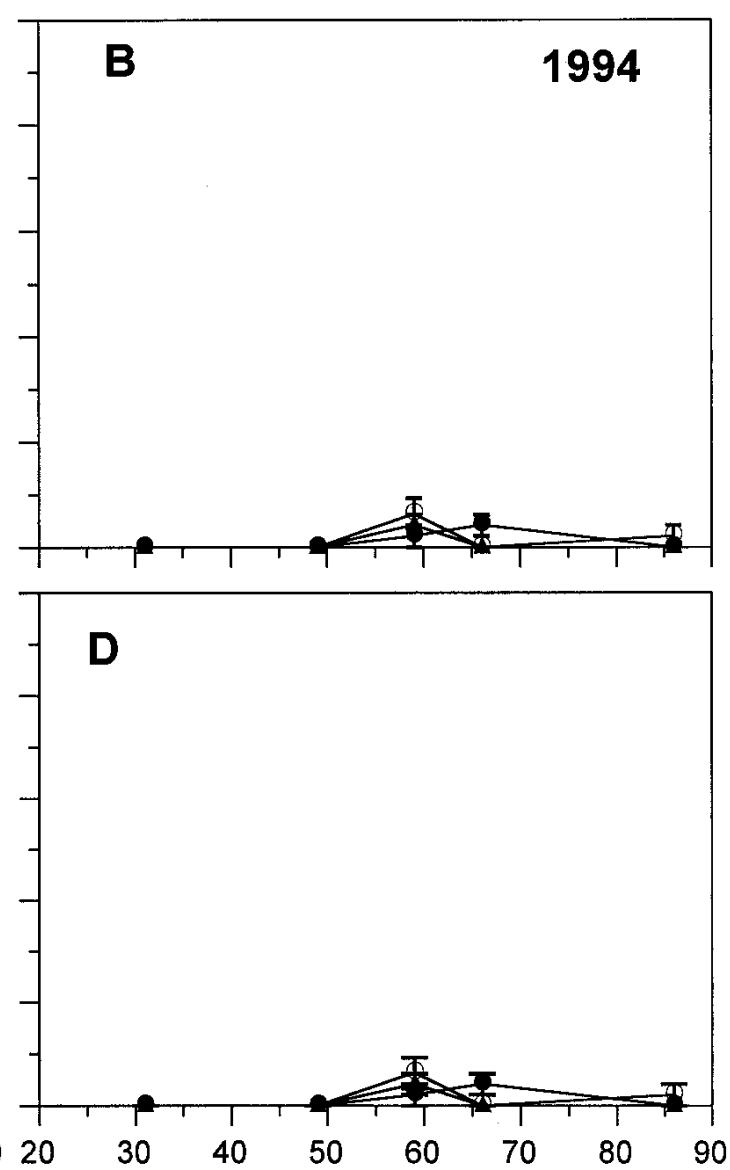

\section{Days after transplanting}

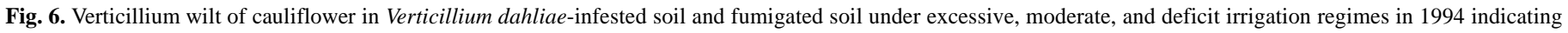
$\mathbf{A}$ and $\mathbf{B}$, wilt incidence and $\mathbf{C}$ and $\mathbf{D}$, wilt severity. Vertical bars are the standard errors of the mean. 


\section{DISCUSSION}

Root growth in cauliflower is affected more by irrigation than by $V$. dahliae. $V$. dahliae infection in cauliflower did not result in significant reductions in root length and shoot growth but affected

TABLE 3. Effects of irrigation and Verticillium dahliae on cauliflower yields ${ }^{2}$

\begin{tabular}{llccc}
\hline Year & Treatment & $\begin{array}{c}\text { Marketable } \\
\text { heads }\end{array}$ & $\begin{array}{c}\text { Unmarketable } \\
\text { heads }\end{array}$ & $\begin{array}{c}\text { Marketable } \\
\text { heads (Kg) }\end{array}$ \\
\hline \multirow{2}{*}{1994} & & & \\
& Control & $54.56 \mathrm{a}$ & $22.89 \mathrm{a}$ & $60.82 \mathrm{a}$ \\
& V. dahliae infested & $54.11 \mathrm{a}$ & $21.11 \mathrm{a}$ & $60.29 \mathrm{a}$ \\
& & $54.61 \mathrm{a}$ & $20.39 \mathrm{a}$ & $60.82 \mathrm{a}$ \\
& Furrow & $54.06 \mathrm{a}$ & $23.61 \mathrm{a}$ & $60.29 \mathrm{a}$ \\
& Subsurface drip & $52.50 \mathrm{~b}$ & $23.67 \mathrm{a}$ & $56.69 \mathrm{~b}$ \\
& Deficit & $53.33 \mathrm{ab}$ & $23.58 \mathrm{a}$ & $60.32 \mathrm{ab}$ \\
Moderate & $57.17 \mathrm{a}$ & $18.75 \mathrm{~b}$ & $64.65 \mathrm{a}$ \\
Excessive & $43.69 \mathrm{a}$ & $12.44 \mathrm{a}$ & $46.02 \mathrm{a}$ \\
Control & $44.00 \mathrm{a}$ & $13.22 \mathrm{a}$ & $46.94 \mathrm{a}$ \\
& V. dahliae-infested & $42.67 \mathrm{a}$ & $10.06 \mathrm{a}$ & $44.19 \mathrm{a}$ \\
& Furrow & $45.03 \mathrm{a}$ & $15.61 \mathrm{a}$ & $48.76 \mathrm{a}$ \\
Subsurface drip & $39.67 \mathrm{a}$ & $14.42 \mathrm{a}$ & $42.82 \mathrm{a}$ \\
& Deficit & $46.63 \mathrm{a}$ & $11.50 \mathrm{a}$ & $50.96 \mathrm{a}$ \\
Moderate & $45.25 \mathrm{a}$ & $12.58 \mathrm{a}$ & $45.65 \mathrm{a}$ \\
\hline
\end{tabular}

${ }^{\mathrm{z}}$ All variables are means from three replications, four beds per replication. Values followed by the same letters within each column are not significantly different according to LSD $(P \leq 0.05)$. Number of marketable and unmarketable heads and weight of marketable heads per plot (single 9-m bed). physiological processes related to hydraulic conductance of cauliflower under field conditions. The interactive effect of irrigation method and $V$. dahliae on root length densities in cauliflower was significant, and only the excessive irrigation regime resulted in extensive root growth. Cauliflower yield was not affected by $V$. dahliae and irrigation method under these experimental conditions, but deficit irrigation regime resulted in yield reductions although it suppressed wilt development on cauliflower. Thus, irrigation regimes designed for disease suppression compromise crop yield and quality. Therefore, adapting these practices for disease management should be weighed against potential yield losses as a result of adapting the practice for disease suppression.

Root growth is an important component in the progress of diseases caused by root pathogens. Root length is of particular importance in the epidemiology of diseases caused by soilborne pathogens because it best reflects the potential number of infection courts (11). In this study, at 5 and $25 \mathrm{~cm}$ from plants, root length densities were affected only by $V$. dahliae in 1 year. Root systems can be significantly different in direct-seeded and transplanted crops (26). While direct seeding of row crops results in extensive root systems, transplanted crops result in a more confined root system $(13,26)$. Nearly all of cauliflower in California is transplanted with 5- to 6-week-old seedlings (26). There is, thus, a considerable lag between transplant establishment and root system expansion in cauliflower. In a cauliflower production system using transplants, plant roots may have a relatively shorter time to come in contact with $V$. dahliae microsclerotia in soil than direct-seeded plants. In direct-seeded cropping systems, the root system is more extensive, has increased opportunity for contact

\section{V. dahliae-infested}

\section{Fumigated control}
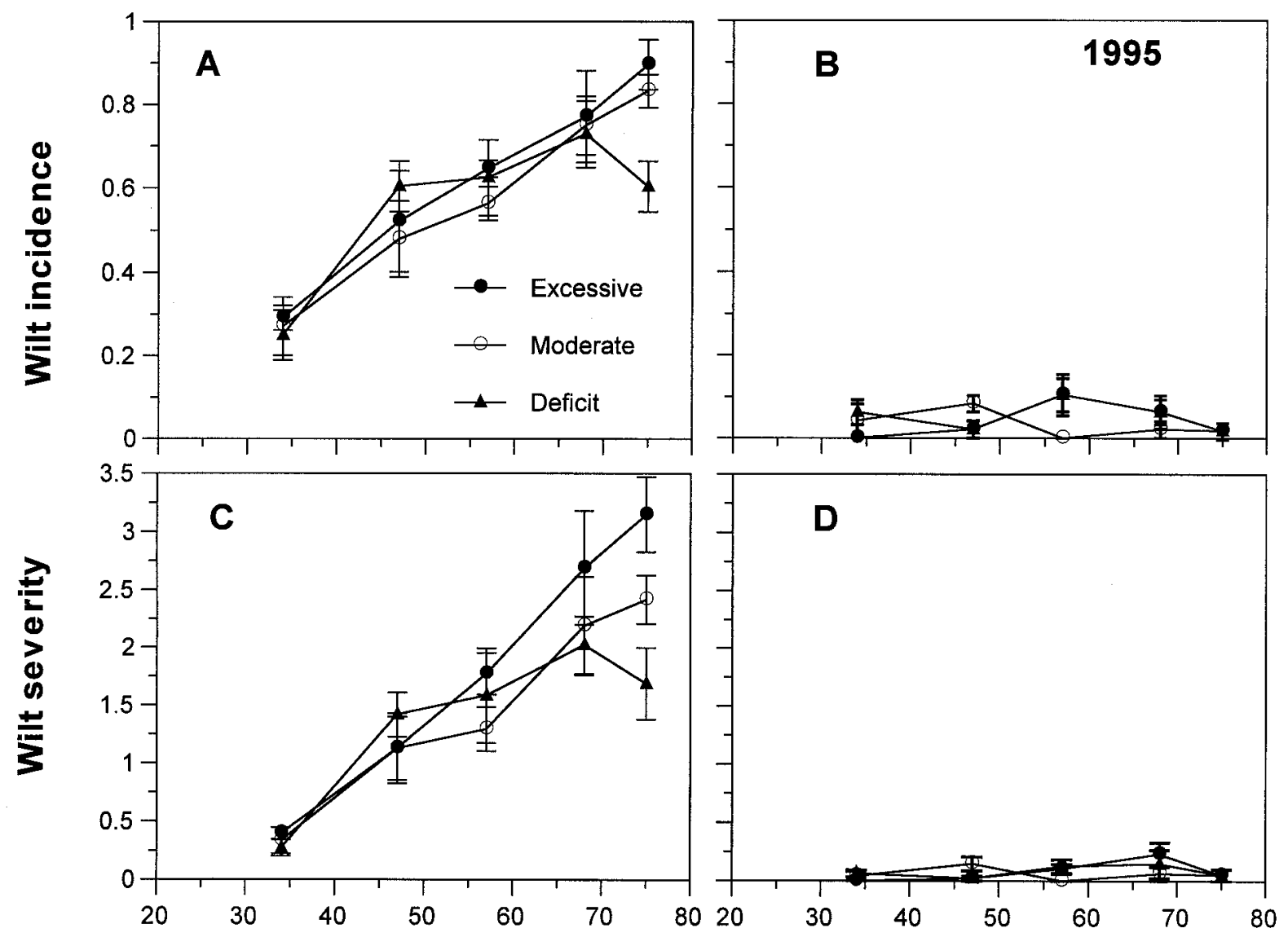

\section{Days after transplanting}

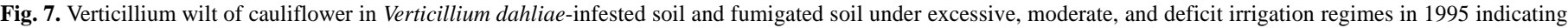
$\mathbf{A}$ and $\mathbf{B}$, wilt incidence and $\mathbf{C}$ and $\mathbf{D}$, wilt severity. Vertical bars are the standard errors of the mean. 
with $V$. dahliae microsclerotia, and thus greater probability of root infection. This may partially explain why no substantial root reductions occurred in $V$. dahliae-infested plots. These results are consistent with that observed in the $V$. dahliae-potato system. In potato production systems also, there is a lag between planting and the establishment of extensive root systems, and thus, $V$. dahliae did not cause substantial reductions in root length in nonfumigated soil (15).

Because different irrigation methods result in significantly different moisture distribution across the planted soil surface, root systems are also expected to be different. Subsurface drip irrigation results in a more localized moisture distribution than furrow irrigation (24). Drip irrigation typically results in a smaller, more confined root system than either sprinkler or furrow irrigation in many vegetable crops $(13,26)$. Based on the moisture distribution patterns under this irrigation system, greater root densities are expected near the source of moisture. As expected, higher root length densities occurred at $5 \mathrm{~cm}$ under subsurface drip irrigation than under furrow irrigation in 1994, but the root length density was greater at $25 \mathrm{~cm}$ from plant in 1995. Both these distances lie within the width of the planting beds where moisture is distributed under subsurface drip irrigation. Furthermore, in a transplanted cauliflower crop, taproots are generally small, and the bulk of the root system is comprised of lateral roots (26). This might explain the similar root distribution under both furrow and subsurface drip irrigation systems and the resultant similar disease incidence and severity.

The quantity of water applied to the cauliflower crop had a major effect on the root length density. Excessive irrigation regime resulted in extensive root growth and severe wilt on cauliflower. Because extensive host root growth is more important in the initial pathogen-root interactions than the growth of the pathogen (mycelial) toward the root, increased root length densities are expected to result in higher disease severity. As expected, root length densities under excessive regime at 5 and $25 \mathrm{~cm}$ from plant were significantly higher than under other regimes. The increased probability of roots coming in contact with $V$. dahliae microsclerotia may have contributed to the increased wilt severity under this management system. Excessive irrigation may have an effect on movement of $V$. dahliae conidia from sporulating microsclerotia toward the root surface, contributing to the increased probability of infection. Furthermore, under excessive irrigation, movement of conidia in the vascular tissue may be unrestricted, which would affect the rate of vascular colonization and subsequent wilt development $(6,7,12,19)$.

Plant growth parameters were variable under the factors considered in this study. The effects of irrigation method and regime significantly affected plant height. Subsurface drip irrigation and deficit regime resulted in reduced plant height but not in the dry weights of leaves and roots. Because the variability was larger than the effects of $V$. dahliae on plant growth parameters, disease effects on the host could not be ascertained under the field conditions.

Physiological responses to Verticillium wilt vary in plant species $(1,2,17,18,28)$. In potato, young, symptomless leaves from plants infected with $V$. dahliae exhibited increased stomatal resistance that reduced $\mathrm{CO}_{2}$ exchange rate in symptomless leaves $(2,3)$. Increased stomatal resistance also was observed in upper young and lower old leaves from cotton plants infected by $V$. dahliae (25). In alfalfa, wilt caused by $V$. albo-atrum reduced photosynthesis by lowering RuBP carboxylase activity instead of increasing stomatal resistance (18). In our microplot study (28), however, increased stomatal resistance was observed in lower $V$. dahliaeinfected leaves but not in upper visually healthy leaves. Similarly, under field conditions in this study, increased stomatal resistance was observed in the lower symptomatic leaves and not in the upper healthy leaves suggesting that the extent to which $V$. dahliae reduced hydraulic conductance in young leaves on cauliflower was less than in other crops $(2,16,25)$.
In summary, both irrigation method and regime had major effects on cauliflower root and shoot growth. $V$. dahliae affected physiological processes related to the hydraulic conductance in cauliflower but not root length and shoot growth. There were no interactive effects of irrigation methods and $V$. dahliae on root length densities, but excessive irrigation regimes resulted in extensive root growth, wilt incidence, and severity. Deficit irrigation regime suppressed wilt development but reduced yield in cauliflower.

\section{ACKNOWLEDGMENTS}

This research was supported in part by the California cauliflower growers. We thank B. Mackey for suggestions on the data analyses, J. M. Duniway for providing the porometer for stomatal resistance measurement, S. Benzen, T. Gonzales, J. Hao, J. Hubbard, S. Koike, M. Lepe, R. Liebhard, and K. Schulbach for assistance, and Natividad Nursery in Salinas for providing cauliflower transplants.

\section{LITERATURE CITED}

1. Ashworth, L. J., Jr., Huisman, O. C., Harper, D. M., and Stromberg, L. K. 1979. Verticillium wilt disease of tomato: Influence of inoculum density and root extension upon disease severity. Phytopathology 69:490-492.

2. Bowden, R. L., and Rouse, D. I. 1991. Effects of Verticillium dahliae on gas exchange of potato. Phytopathology 81:293-301.

3. Bowden, R. L., Rouse, D. I., and Sharkey, T. D. 1990. Mechanisms of photosynthesis decrease by Verticillium dahliae in potato. Plant Physiol. 94:1048-1055

4. Bowers, J. H., Nameth, S. T., Riedel, R. M., and Rowe, R. C. 1996. Infection and colonization of potato roots by Verticillium dahliae as affected by Pratylenchus penetrans and P. crenatus. Phytopathology 86:614-621.

5. Butterfield, E. J., and DeVay, J. E. 1977. Reassessment of soil assays for Verticillium dahliae. Phytopathology 67:1073-1078.

6. Cappaert, M. R., Powelson, M. L., Christensen, N. W., and Crowe, F. J. 1992. Influence of irrigation on severity of potato early dying and tuber yield. Phytopathology 82:1448-1453.

7. Cappaert, M. R., Powelson, M. L., Christensen, N. W., Stevenson, W. R., and Rouse, D. I. 1994. Assessment of irrigation as a method of managing potato early dying. Phytopathology 84:792-800.

8. Gaudreault, S. M., Powelson, M. L., Christensen, N. W., and Crowe, F. J. 1995. Soil water pressure and Verticillium dahliae interactions on potato. Phytopathology 85:1542-1546.

9. Gent, M. P., Ferrandino, F. J., and Elmer, W. H. 1995. Effects of Verticillium wilt on gas exchange of entire eggplants. Can. J. Bot. 73:557-565.

10. Harrison, J. A. C., and Isaac, I. 1969. Effect of main stem number and lateral stem development in potato plants infected with Verticillium alboatrum and V. dahliae. Ann. Appl. Biol. 63:379-387.

11. Huisman, O. C. 1982. Interrelations of root growth dynamics to epidemiology of root-invading fungi. Annu. Rev. Phytopathol. 20:303-327.

12. Ioannou, N., Schneider, R. W., Grogan, R. G., and Duniway, J. M. 1977. Effect of water potential and temperature on growth, sporulation, and production of microsclerotia by Verticillium dahliae. Phytopathology 67:637-644.

13. Jackson, L. E., and Stivers, L. J. 1993. Root distribution of lettuce under commercial production: Implications for crop uptake of nitrogen. Biol. Agric. \& Hortic. 9:273-293.

14. Koike, S. T., Subbarao, K. V., Gordon, T. R., Davis, R. M., and Hubbard, J. C. 1994. Verticillium wilt of cauliflower in California. Plant Dis. 78:11161121.

15. Kotcon, J. B., Rouse, D. I., and Mitchell, J. E. 1984. Dynamics of root growth in potato fields affected by the early dying syndrome. Phytopathology 74:462-467.

16. MacHardy, W. E., Busch, L. V., and Hall, R. 1976. Verticillium wilt of chrysanthemum: Quantitative relationship between increased stomatal resistance and local vascular dysfunction preceding wilt. Can. J. Bot. 54:1023-1034.

17. Nelson, R. 1950. Verticillium wilt of peppermint. Mich. State Univ. Agric. Exp. Stn. Tech. Bull. 221:1-259.

18. Pennypacker, B. W., Knievel, D. P., Leath, K. T., Pell, E. J., and Hill, R. R., Jr. 1990. Analysis of photosynthesis in resistant and susceptible alfalfa clones infected with Verticillium ablo-atrum. Phytopathology 80:1300-1306.

19. Powelson, M. L., and Rowe, R. C. 1993. Biology and management of early dying of potatoes. Annu. Rev. Phytopathol. 31:111-126.

20. Pullman, G. S., and DeVay, J. E. 1982. Epidemiology of Verticillium wilt of cotton: Effects of disease development on plant phenology and lint yield. Phytopathology 72:554-559. 
21. Schnathorst, W. C. 1981. Life cycle and epidemiology of Verticillium. Pages 81-111 in: Fungal Wilt Diseases of Plants. M. E. Mace, A. A. Bell, and C. H. Beckman, eds. Academic Press, New York.

22. Smucker, A. J. M., McBurney, S. L., and Srivastava, A. K. 1982. Quantitative separation of roots from compacted soil profiles by the hydropneumatic elutriation system. Agron. J. 74:500-503.

23. Subbarao, K. V., Chassot, A., Gordon, T. R., Hubbard, J. C., Bonello, P., Mullin, R., Okamoto, D., Davis, R. M., and Koike, S. T. 1995. Host range of Verticillium dahliae from cauliflower and genetic relationships and cross pathogenicities of isolates from different crops. Phytopathology 85:1105-1112.

24. Subbarao, K. V., Hubbard, J. C., and Schulbach, K. F. 1997. Comparison of lettuce diseases and yield under subsurface drip and furrow irrigation. Phytopathology 87:877-883.
25. Tzeng, D. D., and DeVay, J. E. 1985. Physiological responses of Gossypium hirsutum L. to infection by defoliating and nondefoliating pathotypes of Verticillium dahliae Kleb. Physiol. Plant Pathol. 26:57-72.

26. University of California Statewide Integrated Pest Management Project. 1993. Integrated Pest Management for Cole Crops and Lettuce. Publ. 3307.

27. Xiao, C. L., and Subbarao, K. V. 1997. Physiological effects of irrigation and Verticillium dahliae on cauliflower growth. (Abstr.) Phytopathology 87 (suppl.):S105.

28. Xiao, C. L., and Subbarao, K. V. 1998. Relationships between Verticillium dahliae inoculum density and wilt incidence, severity, and growth of cauliflower. Phytopathology 88:1108-1115.

29. Xiao, C. L., Subbarao, K. V., Schulbach, K. F., and Koike, S. T. 1998. Effects of crop rotation and irrigation on Verticillium dahliae microsclerotia in soil and wilt in cauliflower. Phytopathology 88:1046-1055. 